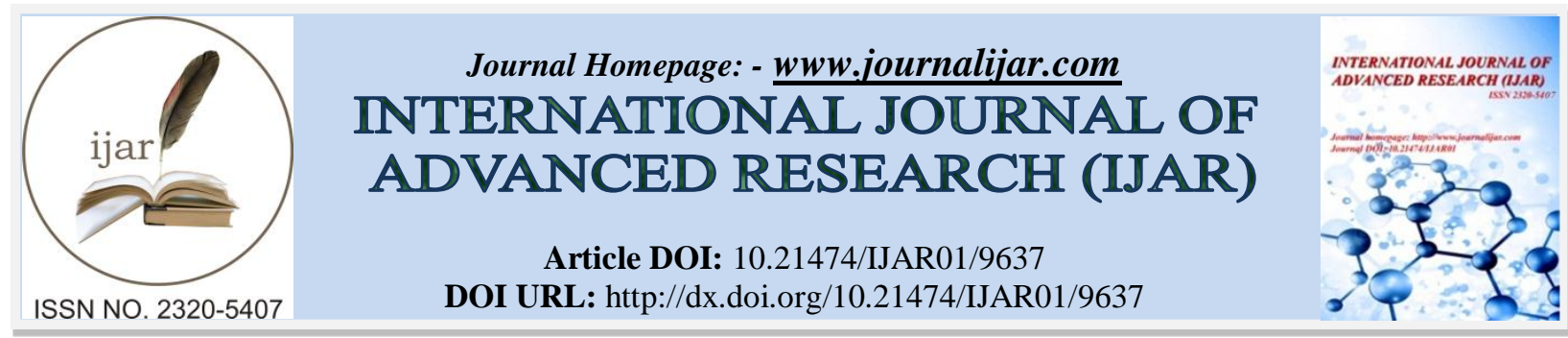

RESEARCH ARTICLE

\title{
"IMPACT OF ACCELERATING US-CHINA TRADE TENSIONS ON THEIR ECONOMY" - AN ATTEMPT TO GUIDE INVESTORS BASED ON EMPIRICAL EVIDENCE.
}

Santhosh.CH ${ }^{1}$ And Dr. Mallikarjun Naik ${ }^{2}$.

1. Research Scholar, Department of Commerce, Karnataka University Dharwad.

2. Assistant Professor, Department of Commerce, Karnataka University PG Centre, Gadag.

\section{Manuscript Info}

Manuscript History

Received: 02 July 2019

Final Accepted: 04 August 2019

Published: September 2019

Key words:-

BSE SENSEX, Capital Asset Pricing

Model, Efficient Frontier, Optimal

Portfolio, US \& China's Economy.

\section{Abstract}

The United States and China's relationship is certainly one of the major consequences in the world today. After 40 years of engagement with successful diplomatic ties the tensions over trade and security have put their relationship at stake. The prolonged US-China trade war has overshadowed all other global issues. Tensions have escalated on how the world's 2 largest economies will find the common ground for peaceful coexistence at the time when both the administrations have been treating their negotiations in terms of distributive bargaining approach rather than integrated bargaining approach.

The ongoing tariff war is just the beginning of this cascade. The financial market accentuated and augmented by uncertainty to erode investments leading to rising unemployment and a lower consumption and all that together puts into a situation of a global growth recession similar to that of a global financial recession. The ongoing trade war has been effecting the investor sentiments, investment sentiments, Consumer sentiments, supply chain disruptions, etc. and has led investors less likely willing to invest in this climate. The short-term interest rate had gone up and investors sentiment been down, the 10 year bond yield had started to decline, which has lead towards an inverted yield curve. If this trade war situation prolongs for a long time, it would become a serious concern, because an inverted yield curve is often considered as a prediction for economic recession by most of the economists.

In this paper an attempt is made to access the impact of the accelerating trade issues between United States and China on their economy. This is done by considering: the financial market data of both the countries, stock indices, financial market data of the top BSE SENSEX companies that have their business activities in both US and China. In order to guide investors in selecting the optimum portfolio investments, the author has assessed the investment prospects of those Indian companies stock through the applications of financial analysis tools such as: Capital asset pricing model, Efficient Portfolio Frontier and Sharp's Optimum Portfolio techniques.

Copy Right, IJAR, 2019,. All rights reserved. 


\section{Introduction:-}

In 2014 when Trump wasn't elected, he tweeted "Remember, china is not a friend of the united states" and was campaigning with the promise of sustaining America first policy. All this escalated in 2015, when Chinese leaders announced to become the words most powerful economies empire by 2025, and followed a slew of protectionism measures with regard to opening up their technology, investments, multinational companies, jobs, transfer agreements and having enforced a number of import restrictions in an attempt to boost domestic business and job. Chinese government pressurized private companies to adjust their vision to china's 2025 vision while providing subsidies worth $\$ 300$ billion of investments, mobilizing state backed companies. While on the other side the US was facing a hike in trade deficit, that is; the total imports of US was around \$3.1 Trillion (2019) while its exports was around $\$ 2.5$ trillion, of which $17.3 \%$ of imports are from China but only $4.8 \%$ of exports to China. That is the US consumers buy about 5 times more than China, that is, $\$ 500$ billion of goods from China, whereas Chinese consumers only buy about $\$ 100$ billion from the United States. Whereas the total deficit of USA is \$621 billion out of which $67 \%$ is to the china, resulting in a large part of trade deficit with China. After his winning of presidential election and took office on January 2017, the concern that the U.S government, the Trump administration, has about the US - China relationship, is that they buy a lot more from china then china buy from America. With this concern Trump administration had started a trade war "in order to modify china's behavior especially in technology transfers and other abusive activities such as subsidies and market limitations and the real purpose isn't to end up with tariffs, but the real purpose is to end up with the level playing field" [Wilbur Ross, US commerce secretary].

The financial market accentuated and augmented by uncertainty to erode investments leads to rising unemployment and lower consumption had led Investors worry with the threat being of global economy going to slow down and had led them put more money in long term bonds yields which has been above $3 \%$, since 10 years treasury have fallen to $2.5 \%$, its almost the $20 \%$ change. This has led to the flattening of yield curve and the curve is headed towards the bear market, which will soon result in an inverted yield curve is this trade war continues for a long time.

\section{Impact Of US- China Trade War On American Economy}

Trade with china accounts for 60 percent of trade volumes of the port. So US-China trade relationship matters a great deal to the US economy. Much of the consumptions in the US are produced by Chinese company, lots of the components sourced by the US companies are produced by Chinese company. Being the china one of the largest purchaser of farm products like soya beans, this trade war has made a damage to American farmers which has made them worry about losing the Chinese market, thus it has become extremely detrimental, particularly in the agricultural sector, which is the huge driver of US economy. In US the prices of goods and services are raising, the prices of inputs are raising, economic uncertainty is raising which is causing the investments to shrink, which has resulted in the reduction in productivity growth and has led to reduction in the rate of economic growth, which mooted in reduction in wages which effects the standard of living of the people, Sending financial market into a tail spin. Raised cost for importers, consumers, retailers, manufacturers, etc. US economic growth slowed to $2.1 \%$ in the $2^{\text {nd }}$ Quarter of 2019. The country's manufacturing output has also declined for 2 consecutive quarters, economists had warned that the US could tip into a recession by the end of 2020. Evident by this "US will fall as a world's economic leader by the year 2030. Standard and chartered bank the china and India would surpass the US as the most powerful economy" [Money Watch, News Report]. With this ongoing economic slowdown like situation keeping investment and investors in view, the current study have been conducted in order to analyze the United States market economy by taking weekly data of market value for the past 5 years of American stock indices and 10 year Bond yield of US Government in order to guide investors with their investments.

American stock indices such as: S\&P 500, Dow Jones Industrial Average, NASDAQ Composite, Wilshire 5000 Total Market Index and NYSE AMEX Composite Index, which are the most commonly followed equity indices, measuring the stock performances of more than 5000 large and medium companies that are listed on various stock exchanges in the United States. These indices are considered to be the best representations of the US stock markets and US economy. Sum of these indices are capitalization weighted index while some index valuations are based on the sum of the price of one share of stock for each component company. The majority component stocks of these indices includes only companies listed in the United States, while some of them includes stocks of companies that are incorporated in other countries. When come to assessment of the company's stock that could be included in the index includes various selection criteria by the specified committee which assesses the stocks based on criteria's such as market capitalization, Liquidity, domicile, public float, sector classification, financial viability, and the length of time publicly traded and stock exchanges. While in some indices selection of components are strictly rule 
based. To remain indicative of performance of the market and economy in the United States, the constituent stocks are changed time to time.

\section{Impact Of US- China Trade War On Chinese Economy}

Asia is contributing half of the world group, where china contributes nearly half of the Asia's contribution to the world economy. Chinese economy which had grown 42 times larger than it was in 1980s, with the country more relied on cheap plentiful labor to become the largest manufacturer and export of goods globally accounting for a fifth of global trade. This shift had headed down again the official figure says the economy is growing by $6.6 \%$ but independent economist think it may be closer to $5.5 \%$ or even more . 2018 was the weakest year for the china since 1980 because of economic slowdown due to raise in wages, and had resulted in china losing its competitive advantage over other countries. This resulted in china to rely more on exports through focusing on domestic products and restrict free flow of imports. The measures imposed by the country to curb lending had hit spending and investment leading into a slowdown. With this ongoing trade war with US, The size of china's total borrowings had grown three times the size of the countries annual income. Furthermore Chinese currency had the worst weakest slowdown back to back since May 2019 in the entire history of china as a modern nation. In the terms of actual global value of Chinese's stocks has declined by more than 30 percent. Manufacturing activity which contributes to the $2 / 5^{\text {th }}$ of the country's economy contracted for the first time in 2 years, price of raw material for industries which are manufactured in china has been falling as demand had reduced. Household spending is going up on a slower phase, while retail sales are expanding at their slowest rate in 15 years, cars sales have fallen for the first time since 2 decades. This view on the economy of the country has resulted in investors to worry about the investment prospects and has led to the decline in investors while investors are being cautions in investing. With this ongoing economic slowdown like situation keeping investment and investors in view, the current study have been conducted in order to analyze the china's market economy by taking weekly data of market value for the past 5 years of American stock indices and 10 year Bond yield of US Government in order to guide investors with their investments

Chinese stock Indices that are considered includes Hang Seng Index, SSE Composite Index, CSI 300 Index, SZSE A Share Index and HANG SENG China Enterprises index which are capitalization-weighted index, while some are free float adjusted market capitalization weighted stock market index and are the most commonly used indicator to reflect stock market performances and the china's economy, the constituents in these indices include listed stocks in Chinese stock exchanges and reflects the stock performances in different sectors. The selection of the constituent stock includes the use of extensive analysis of stocks, together with external consultations. Changes and issues pertaining to the indices including constituent changes and development of new indices are based on the advice of the constituted independent advisory committee.

\section{Impact Of US - China Trade War On Indian Economy}

India which is the close ally of both US and China is witnessing an economic downturn. The country's exports rose marginally in April by $0.64 \%$ to the US $\$ 26$ billion, while the imports rose by $4.5 \%$ to 41.4 billion compared to a year ago month, trade deficit widened too US \$15.33 billion in April 2019 for US \$13.72 billion. The companies which is operating globally are witnessing the sharp downturn in sales, many foreign investors are pulling money out of the Indian stock markets leading to high volatility, World Bank has pushed India down by 2 ranks in its global GDP index and India is now the $7^{\text {th }}$ largest Economy in the world.

Components of BSE SENSEX stocks of companies such as Tata Motors Limited [Automobile Sector], ITC Limited [Cigarettes \& FMCG Sector], Hindustan Unilever Limited [Personal Care], Tata Consultancy Services Limited [Software], Larsen \& Toubro Limited [Infrastructure], Reliance Industries Limited [Conglomerate], State Bank of India [Banking Sector], Housing Development Finance Corporation Limited [Finance Sector], which are some of the largest and most actively traded stocks and are the representatives of various industrial sectors of the Indian Economy and also are the companies that have their operations throughout the world especially in United States of America and China and are listed in the USA and Chinese Stock Exchanges and are traded in most of their stock exchanges. Thus for the current study is conducted to analyze the market trends of these companies which represents different sectors of Indian economy and are having their stocks listed in both USA and China markets and are being traded in their exchanges are considered for the analysis.

\section{Need of the Study}

As tensions grew across the world, this trade war between United States and china had become messy and has created lots of uncertainties which had continued to persist. The resulting factor have undermined the real 
investments and has reduced the global GDP growth even more and had led towards a continuous slowdown of the global economy. The serious concern is that it might lead to a global recession evident by the inverted yield curve. Investors are cautious in making investment in this climate, if investments do not pick up at this juncture this would become a major cause of concern for the global economic downturn. Therefore through this study the authors have tried to guide investors in selecting an efficient portfolio for investment, which would intern help the economy to move towards normalcy.

\section{Objectives of Study:}

The main objective of this study is to guide the investors with regard to efficient portfolio construction in the wake of accelerating trade tensions and increasing diplomatic crises between the 2 largest economies [United States and China] of the world.

1. To study and understand the ongoing trade war like situation between the 2 largest economies of the world such as USA and China

2. To estimate the impact of this unrest between USA and China on both of their economy.

3. To study the impact of this crises on the stock market performances of Indian companies which are traded in both the countries stock exchanges and having their operations in both the countries.

4. To guide the investors in undertaking investment decision and help with regard to the construction of optimum portfolio.

\section{Methodology:-}

Sources of data:

Basically this paper depends upon secondary data related to weekly changes in stock market trends from 01/09/2014 to 31/07/2019 of various stock indices of China, United States and India are considered and stock market of top BSE listed Indian companies that are operating and listed in both US and China are considered in order to assess their performance. The data on weekly changes in 10 year Government bond yield of Indian Government, 10 year Government bond yield of United States, 10 year Government bond yield of China have been collected. The collected data have been classified into weekly stock market trends before the strain in bilateral trade ties between US and China and after the strain in bilateral trade ties between US and China considering February 2017, the time when Trump was elected as US president and had started waging trade war against China as the beginning of the trade tensions between the countries. The data was collected from yahoo finance website, money control website, daily National News Papers, International Journal Articles, Weekly and Monthly Business magazines and by Net.

\section{Tools of Analysis:}

Here the attempt was to guide investors in selecting an efficient optimum portfolio for investment at the times when there is a slowdown in global economy and at the times when economists are predicting of global recession like situation due to accelerating trade tensions between number of countries, especially China and US. Therefore to satisfy the above stated objectives, data analysis have been done using financial data analysis tools such as calculation of Return, Standard Deviation, Multiple Regression, Capital Asset Pricing Model, Efficient portfolio Frontier and Sharp's Optimum Portfolio. Final interpretation and suggestions have been drawn as result of the study through the usage of graphs and charts for better understandings.

Data Analysis and Interpretation:

Table 1:-Countries Stock market performance Before and After Bilateral Trade Tensions

\begin{tabular}{|c|l|c|c|c|c|}
\hline \multirow{2}{*}{$\begin{array}{c}\text { Country } \\
\text { United States } \\
\text { of America }\end{array}$} & Stock Index & \multicolumn{3}{c|}{ Before } & \multicolumn{2}{c|}{ After } \\
\cline { 2 - 6 } & Return & Risk & Return & Risk \\
\cline { 2 - 6 } & Dow Jones Industrial Average & 0.29 & 4.82 & 0.00 & 3.91 \\
\cline { 2 - 6 } & NASDAQ Composite & 0.24 & 4.76 & 0.04 & 3.80 \\
\cline { 2 - 6 } & Wilshire 5000 Total Market Index & 0.35 & 4.88 & 0.11 & 4.10 \\
\cline { 2 - 6 } & NYSE AMEX Composite Index & 0.28 & 4.83 & 0.00 & 3.90 \\
\hline \multirow{4}{*}{ China } & HANG SENG INDEX & 0.16 & 5.34 & -0.23 & 4.34 \\
\cline { 2 - 6 } & SSE Composite Index & 0.09 & 3.19 & 0.12 & 2.82 \\
\cline { 2 - 6 } & CSI 300 Index & 0.34 & 4.15 & 0.05 & 2.74 \\
\cline { 2 - 6 } & SZSE A SHARE INDEX & 0.29 & 4.05 & 0.00 & 1.84 \\
\cline { 2 - 6 } & HANG SENG China Enterprises IND & 4.71 & -0.18 & 3.24 \\
\cline { 2 - 6 } & & 0.04 & 3.88 & 0.81 & 3.17 \\
\hline
\end{tabular}




\section{Source: Authors Compilation}

\section{Chart 1:-Countries Stock market performance Before and After Bilateral Trade Tensions}

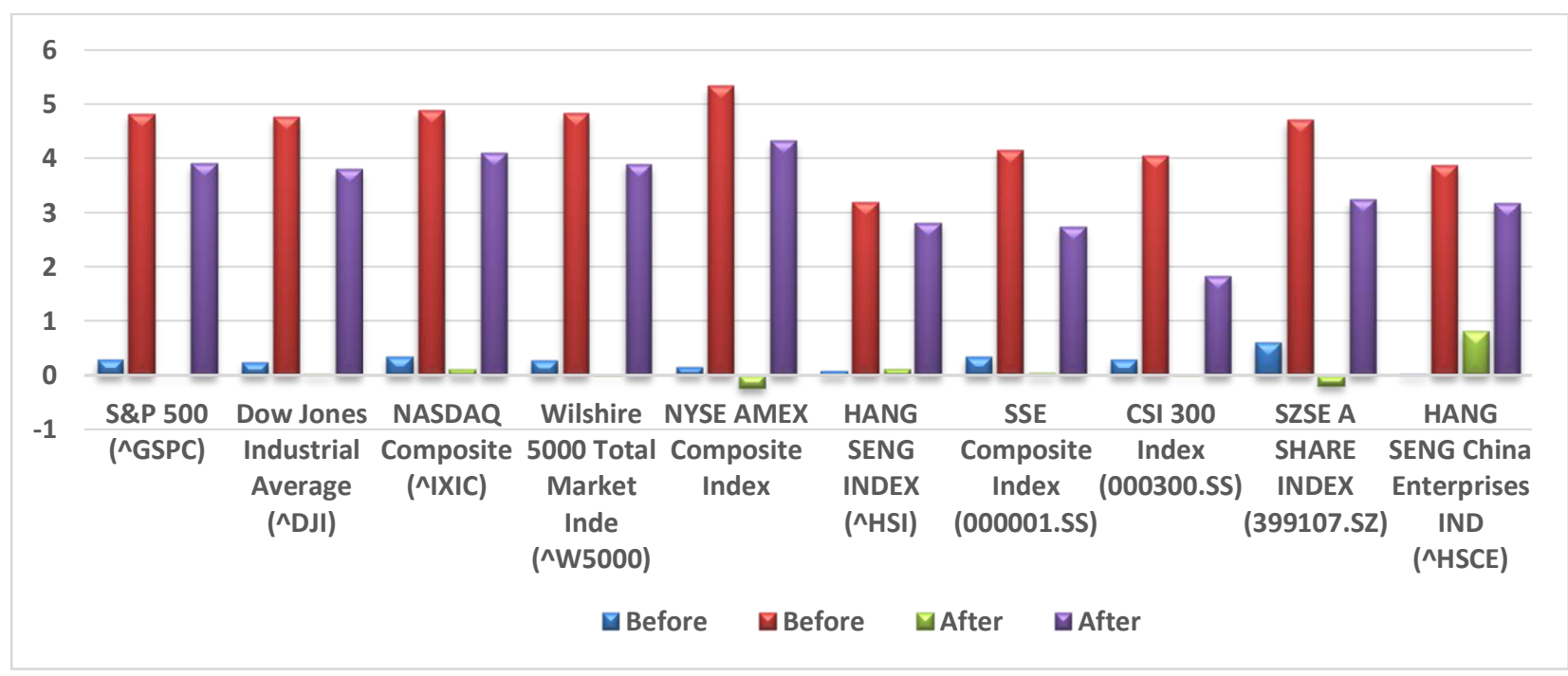

Source: Authors Compilation

From Table 1 and Chart 1 it could be observed that the Excess mean returns of major Stock market indices of United States after the downgrade of Bilateral trade ties was showing negative growth of 0.07 percent of that of the previous 2.5 years (before the downgrade of Bilateral trade ties) while the Excess risk (Standard deviation) associated with the return after the downgrade of Bilateral trade ties has grown by 0.81 percent from that of the previous 2.5 years (before the downgrade of Bilateral trade ties). Whereas the Excess mean returns of major Stock market indices of China after the downgrade of Bilateral trade has shown a growth of 0.59 percent of that of the previous 2.5 years (before the downgrade of Bilateral trade ties) while the Excess risk (Standard deviation) associated with the return after the downgrade of Bilateral trade ties has grown by 0.69 percent from that of the previous 2.5 years (before the downgrade of Bilateral trade ties).

Therefore It could be understood that the though the trade deficit of the United States of America might have lowered over the period of time, the stock market return proportionate to the risk factor, which is associated with the country's economic development factor have impacted to the larger extent with the negative growth than that of China's market return which is associated with its countries economy.

\section{Capital Asset Pricing Model}

CAPM is useful to find the minimum return the security should yield to satisfy the current level of risk. The risk averse nature of the investors is the underlying factor for this behavior. The capital pricing theory helps the investors to understand the risk and return relationship of the securities. It also explains how assets should be priced in the capital market.

$$
R i=R f+\beta(R m-R f)
$$

Note: Where $R f$ means the risk free rate of return, i.e. return given by government T-Bills or Long term yield

The general idea behind CAPM is that what proportion of return investors earn over and above the minimum return he is going to earn if he had invested the same amount in the risk less or minimum risk security such as Government bonds which is the safer investment avenue. The excess return the investors gains is due to the extra risk he undertakes and for the extra time he has invested by taking higher risk. In CAPM systematic risk is considered which is also called as market beta which compares the returns of the asset to the market once a period of time and to the market premium $(R m-R f)$. 
Table 2:-Before Bilateral Trade Tensions

\begin{tabular}{|c|c|c|c|c|c|c|c|c|}
\hline Name & $\begin{array}{c}\text { Actua } \\
\text { l } \\
\text { Retur } \\
\text { n }\end{array}$ & $\underset{\mathbf{k}}{\operatorname{Ris}}$ & $\begin{array}{l}\text { Systemat } \\
\text { ic risk }\end{array}$ & $\begin{array}{l}\text { Unsystema } \\
\text { tic risk }\end{array}$ & $\begin{array}{c}\text { CAPM } \\
- \\
\text { Expect } \\
\text { ed } \\
\text { Return }\end{array}$ & $\begin{array}{c}\text { Variatio } \\
\text { ns in } \\
\text { returns }\end{array}$ & $\begin{array}{c}\text { Perce } \\
\text { nt of } \\
\text { Chan } \\
\text { ge }\end{array}$ & $\underset{\mathbf{k}}{\operatorname{Ran}}$ \\
\hline Tata Motors Limited & 0.004 & $\begin{array}{c}0.04 \\
7\end{array}$ & 1.099 & 0.037 & 0.002 & 0.001 & $144 \%$ & \\
\hline ITC Limited & 0.002 & $\begin{array}{c}0.03 \\
7 \\
\end{array}$ & 0.814 & 0.029 & 0.002 & 0.000 & $99 \%$ & \\
\hline Hindustan Unilever Limited & 0.004 & $\begin{array}{c}0.03 \\
8\end{array}$ & 0.671 & 0.032 & 0.002 & 0.002 & $234 \%$ & 2 \\
\hline $\begin{array}{c}\text { Tata Consultancy Services } \\
\text { Limited }\end{array}$ & 0.004 & $\begin{array}{c}0.03 \\
4 \\
\end{array}$ & 0.638 & 0.029 & 0.001 & 0.003 & $300 \%$ & 1 \\
\hline Larsen \& Toubro Limited & 0.005 & $\begin{array}{c}0.05 \\
0\end{array}$ & 1.393 & 0.031 & 0.003 & 0.001 & $147 \%$ & 3 \\
\hline Reliance Industries Limited & 0.002 & $\begin{array}{c}0.03 \\
9\end{array}$ & 1.060 & 0.025 & 0.002 & 0.000 & $89 \%$ & \\
\hline State Bank of India & 0.004 & $\begin{array}{c}0.06 \\
0\end{array}$ & 1.571 & 0.039 & 0.003 & 0.001 & $122 \%$ & \\
\hline $\begin{array}{c}\text { Housing Development } \\
\text { Finance Corporation Limited }\end{array}$ & 0.003 & $\begin{array}{c}0.04 \\
2\end{array}$ & 1.133 & 0.027 & 0.002 & 0.001 & $122 \%$ & \\
\hline
\end{tabular}

Source: Authors Compilation

From Table 2, it could be observed that selected BSE SENSEX indexed companies which have their operations both in US and China and has been listed in the stock exchanges of both the countries are performing well for the past 2.5 years (Before the breakdown in bilateral ties) of which stocks of Tata consultancy services, Hindustan Unilever, Larsen \& Toubro are presenting higher growth prospects.

Table 3:-After Bilateral Trade Tensions

\begin{tabular}{|c|c|c|c|c|c|c|c|c|}
\hline Name & $\begin{array}{c}\text { Actu } \\
\text { al } \\
\text { Retur } \\
\mathbf{n}\end{array}$ & $\underset{\mathbf{k}}{\operatorname{Ris}}$ & $\begin{array}{l}\text { Systema } \\
\text { tic risk }\end{array}$ & $\begin{array}{l}\text { Unsystema } \\
\text { tic risk }\end{array}$ & $\begin{array}{c}\text { CAPM } \\
- \\
\text { Expect } \\
\text { ed } \\
\text { Return }\end{array}$ & $\begin{array}{l}\text { Variatio } \\
\text { ns in } \\
\text { returns }\end{array}$ & $\begin{array}{c}\text { Percenta } \\
\text { ge of } \\
\text { Change }\end{array}$ & $\begin{array}{c}\text { Ran } \\
\text { ks }\end{array}$ \\
\hline Tata Motors Limited & $\begin{array}{c}- \\
0.006\end{array}$ & $\begin{array}{c}0.05 \\
3\end{array}$ & 1.209 & 0.046 & 0.003 & -0.008 & $-208 \%$ & \\
\hline ITC Limited & 0.002 & $\begin{array}{c}0.03 \\
0\end{array}$ & 0.077 & 0.025 & -0.001 & 0.003 & $-293 \%$ & \\
\hline Hindustan Unilever Limited & 0.006 & $\begin{array}{c}0.02 \\
8 \\
\end{array}$ & 0.086 & 0.022 & -0.001 & 0.006 & $-900 \%$ & \\
\hline $\begin{array}{c}\text { Tata Consultancy Services } \\
\text { Limited }\end{array}$ & 0.005 & $\begin{array}{c}0.03 \\
4\end{array}$ & 0.065 & 0.031 & -0.001 & 0.006 & $-800 \%$ & \\
\hline Larsen \& Toubro Limited & 0.004 & $\begin{array}{c}0.03 \\
2\end{array}$ & 1.077 & 0.022 & 0.002 & 0.001 & $152 \%$ & \\
\hline Reliance Industries Limited & 0.010 & $\begin{array}{c}0.08 \\
7\end{array}$ & 1.547 & 0.080 & 0.004 & 0.006 & $266 \%$ & 2 \\
\hline State Bank of India & 0.024 & $\begin{array}{c}0.34 \\
0\end{array}$ & 0.567 & 0.340 & 0.001 & 0.024 & $3067 \%$ & 1 \\
\hline
\end{tabular}

Source: Authors Compilation

From Table 3, It Could be noted that market value of companies such as Hindustan Unilever, Tata Consultancy Services, ITC Limited and Tata Motors has plunged to the new-low for the past 2.5 years and can be seen underperforming with negative growth, whereas State Bank of India market value has grown extensively and has 
been performed well, while other companies such as Reliance Industries limited, Larsen \& Toubro and Housing Development Finance Corporation have shown a moderate growth.

From the above comparison it is visible that the Indian companies which are operating in both USA and China have shown a moderate growth for the past 2.5 years [2013 to 2016] but has never underperformed or has shown a negative growth. Whereas after the downgrade of Economic and Diplomatic ties between the 2 largest economies of the world it could be ascertained that some of the company's stock price has been showing a negative growth. Overall it could be observed that this issue has a negative economic impact on the corporate entities.

Table 4:-Representation of Returns and Variations in Return of Indian Companies before and after Bilateral Trade Tensions

\begin{tabular}{|c|c|c|c|c|}
\hline & $\begin{array}{c}\text { Return } \\
{[\text { Before] }}\end{array}$ & $\begin{array}{c}\text { Return } \\
{[\text { After] }}\end{array}$ & $\begin{array}{c}\text { Risk } \\
{[\text { Before] }}\end{array}$ & Risk [After] \\
\hline Tata Motors Limited & 0.003500 & -0.005600 & 0.001070 & -0.008260 \\
\hline ITC Limited & 0.001800 & 0.001900 & -0.000010 & 0.002530 \\
\hline Hindustan Unilever Limited & 0.003500 & 0.005500 & 0.002020 & 0.006150 \\
\hline Tata Consultancy Services Limited & 0.004300 & 0.005400 & 0.002880 & 0.006090 \\
\hline Larsen \& Toubro Limited & 0.004500 & 0.003500 & 0.001420 & 0.001190 \\
\hline Reliance Industries Limited & 0.002100 & 0.009700 & -0.000260 & 0.006070 \\
\hline State Bank of India & 0.004200 & 0.024400 & 0.000750 & 0.023580 \\
\hline Housing Development Finance Corporation & 0.003000 & 0.004900 & 0.000540 & 0.002380 \\
\hline
\end{tabular}

Source: Authors Compilation

Chart 2:-Representation of Returns and Variations in Return of Indian Companies before and after downgrade of Diplomatic ties

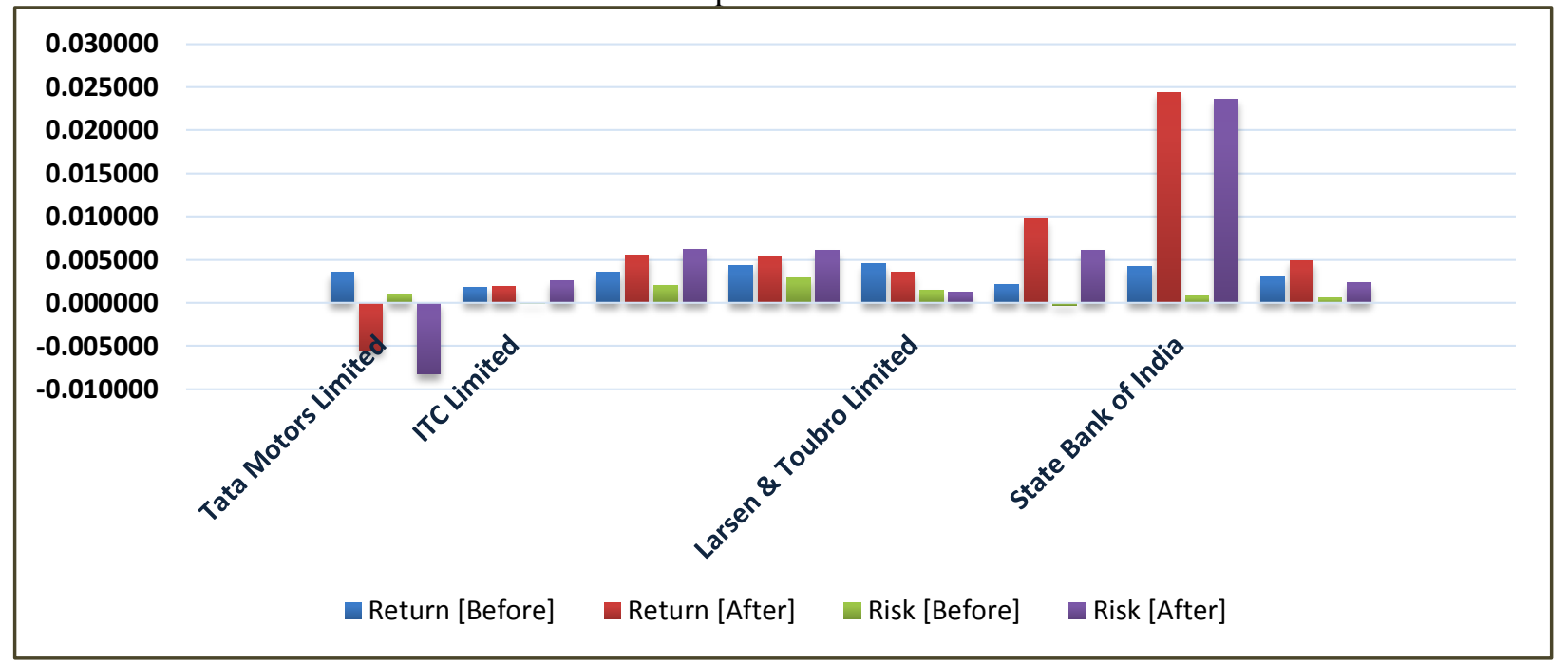

Source: Authors Compilation

From Table 4 and Chart 2, it can be observed that the mean return of Indian companies stock after the downgrade in bilateral trade ties have grown 186.46 percent more than that of the previous 2.5 years duration (before the downgrade in bilateral trade ties), while the Overall risk (Standard deviation) of the Companies after the downgrade in bilateral trade ties have grown to the extent of 472.41 percent over and above the deviation in return during the previous 2.5 years (before the downgrade in bilateral trade ties). Therefore it could be ascertained that the risk associated with the moderate growth in return over a period of time is abnormally higher.

Table 5:-Representation of changes in systematic Risk [Beta] of selected companies before and after Bilateral Trade Tensions

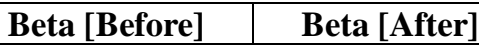




\begin{tabular}{|c|c|c|}
\hline & & \\
\hline Tata Motors Limited & 1.099 & 1.209 \\
\hline ITC Limited & 0.814 & 0.077 \\
\hline Hindustan Unilever Limited & 0.671 & 0.086 \\
\hline Tata Consultancy Services Limited & 0.638 & 0.065 \\
\hline Larsen \& Toubro Limited & 1.393 & 1.077 \\
\hline Reliance Industries Limited & 1.060 & 1.547 \\
\hline State Bank of India & 1.571 & 0.567 \\
\hline Housing Development Finance Corporation Limited & 1.133 & 1.151 \\
\hline
\end{tabular}

Source: Authors Compilation

Chart 3:-Representation of changes in systematic Risk [Beta] of selected companies before and afterBilateral Trade Tensions

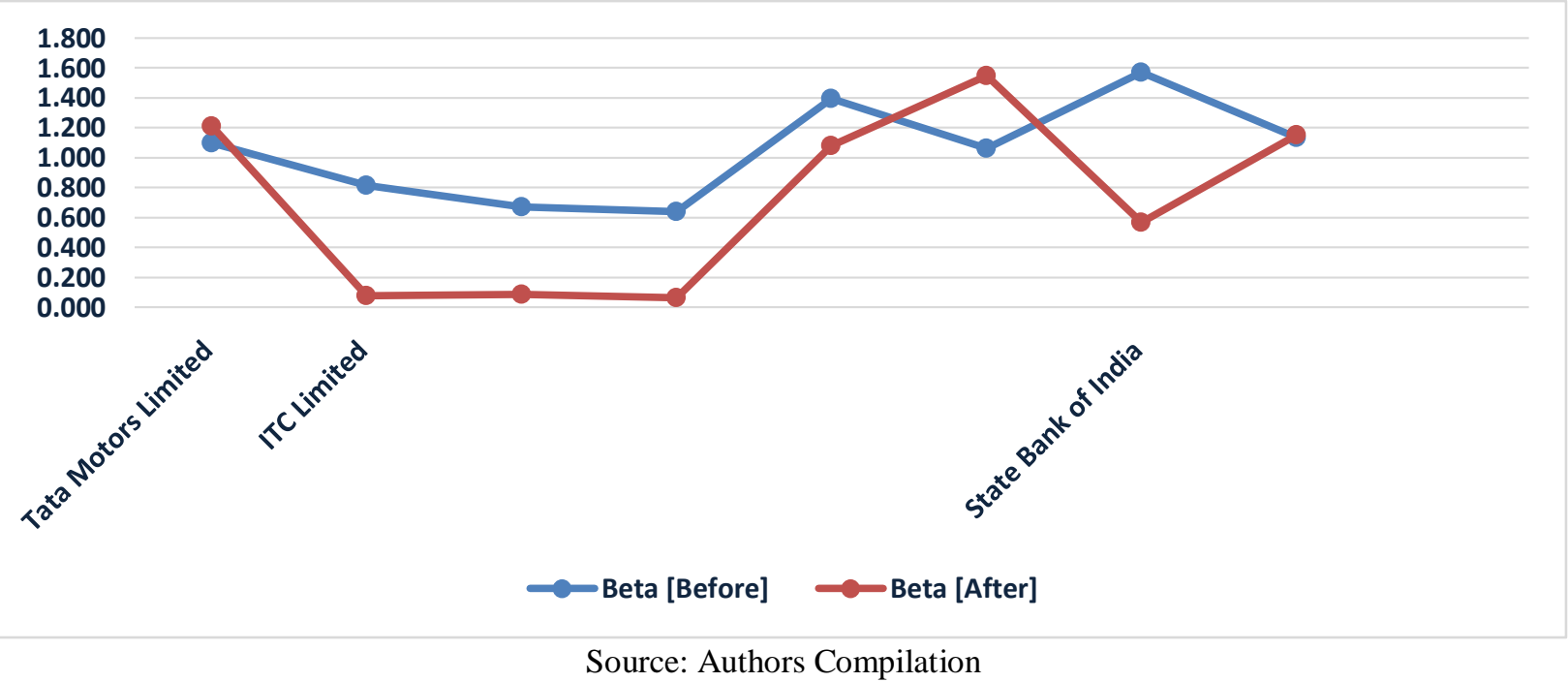

Here Table 5 and chart 3 represents the variations in stock market value of selected companies due to pure market related issues, that is beta of the stock ascertained through the computation of CAPM return of the stock by applying multiple regression technique using excel software for better results and data interpretation. The above chart exhibits the beta of individual companies which in turn represents various industrial sectors of the economy. The influence of market related risk on performance of companies such as Tata Motors, Reliance Industries, Housing Development Finance Corporation have increased during the period of 2.5 years. In this study the 10 year bond yield of US Government, 10 year bond yield of Chinese Government and 10 Years bond yield of Indian government is taken as the measure of risk free rate of return i.e. the minimum return from an investment.

\section{Efficient Optimum Portfolio Frontier:}

The risk and return of all portfolio or stocks plotted in risk-return space would be dominated by efficient stocks and portfolios. Stocks may be selected randomly from capital market. To make effective combination in selection of stock, this concept can be used.

Thus this concept is considered very useful in portfolio theory because any rational investor would not choose any point in the lower part of the curve because he is not considered to be rational if he does so. He can get higher return for the same level of risk if he choose the point (investment option) on the upper part of the curve. 
Chart 4:-Representing the Efficient Frontier Before Bilateral Trade Tensions

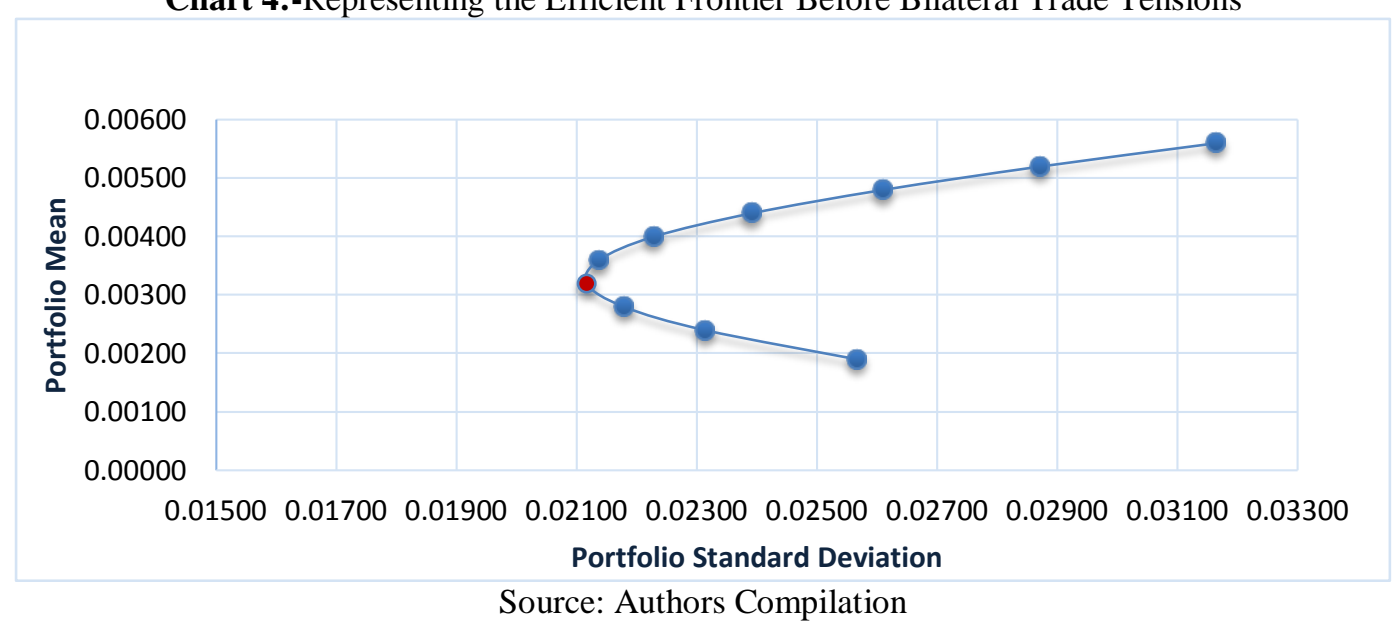

Having portfolio standard deviation on "X-Axis" and Portfolio Mean on "Y-Axis". That means portfolio efficient frontier is a graph that shows the relationship between the portfolio standard deviation which is the major risk and the portfolio mean which is the measure of return. Whereas each point on the portfolio frontier represents the combination of return and the risk. Any points on the lower part of the curve is inefficient and gives lower return for the higher risk we assume when compared to top part of the curve. Therefore any point that lies on the upper part of the curve is said to be the efficient portfolio frontier. Whereas any point which falls on the lower part of the curve are called inefficient portfolio frontier. It could be understood that the portfolio consisting of companies stocks such Tata Motors, Hindustan Uniliver, Tata consultancy services, Larsen \& Toubro and State Bank of India; companies lies above the point of minimum variance and are considered as optimum portfolio.

Chart 5:-Representing the Efficient Frontier after Bilateral Trade Tensions

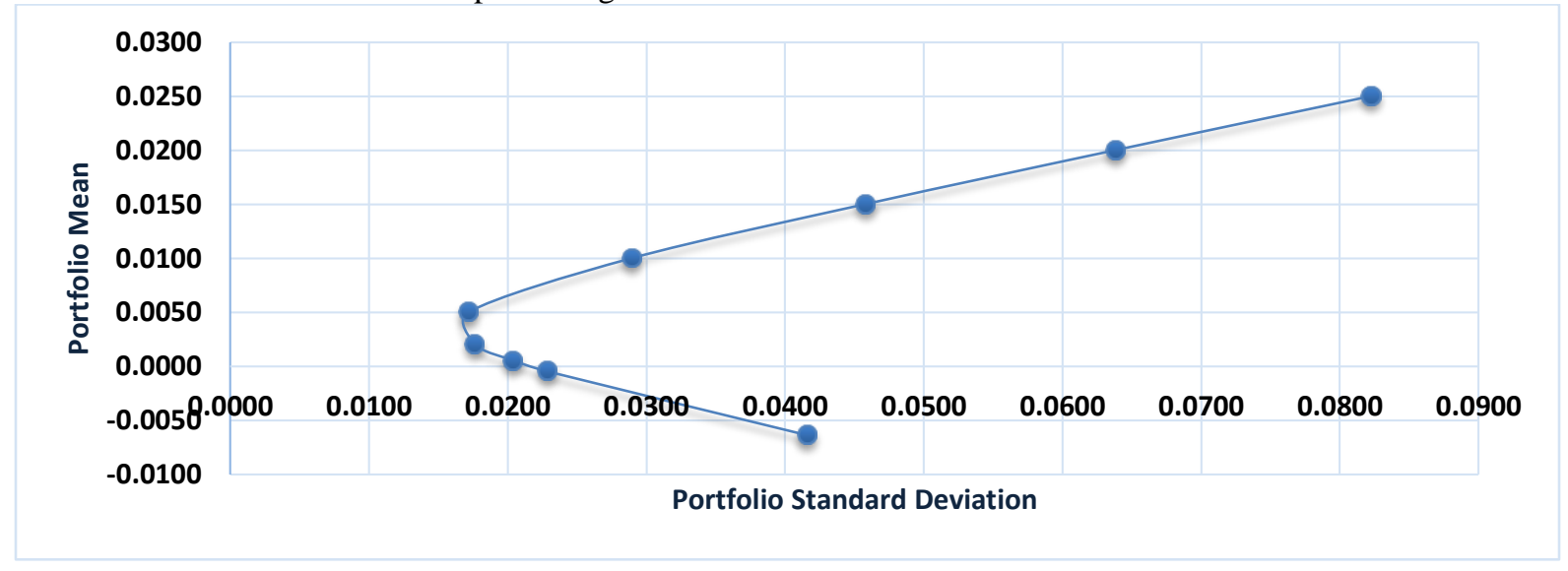

Source: Authors Compilation

The portfolio consisting of companies stocks such as State Bank of India and Reliance Industries limited lies above the point of minimum variance and are considered as optimum portfolio. It could be noted that market performance of State Bank of India has seen a higher than normal growth and has an ability to provide higher return for comparatively lower risk.

\section{Sharp Optimum Portfolio}

A model developed by Sharp for the selection of appropriate securities in the portfolio. According to this model the selection of any stock is based on excess return over beta ratio.

$$
\frac{R i-R f}{\beta i}
$$

Where, 
$R i=$ The expected return of individual stock

$R f=$ The return on the riskless asset

$\beta i=$ The expected change in the rate of return on stock I associated one unit change in the market return

The excess return is the difference between the expected return on the stock and the riskless rate of interest such as the rate offered on the government security or Treasury bill. The excess return of the beta ratio measures the additional return on a security (excess of the riskless asset return) per unit of systematic risk or non-diversifiable risk. The ratio provides a relationship between potential risk and reward. Ranking of the stocks are done on the basis of their excess return to beta. Portfolio managers would select the stock portfolio which has the higher ratio. The selection of the stock depends on a unique cut-off rate such that all the stock with the higher ratios are included and the stock with lower ratios are left off. The cut-off point is denoted by $\mathrm{C}^{*}$. Further the optimum mix of securities can be selected on the basis of $Z^{*}$.

Table 6:-Sharp optimum portfolio Before Bilateral Trade Tensions

\begin{tabular}{|c|c|c|c|c|c|}
\hline & TML & HUL & TCS & L\&T & SBI \\
\hline $\begin{array}{c}\text { Proportion of Portfolio } \\
\text { Investment }\end{array}$ & $\mathbf{4 \%}$ & $\mathbf{2 4 \%}$ & $\mathbf{5 6 \%}$ & $\mathbf{1 6 \%}$ & $\mathbf{0 \%}$ \\
\hline Portfolio Return & \multicolumn{5}{|c|}{$\mathbf{0 . 4 1 \%}$} \\
\hline Portfolio Risk & \multicolumn{7}{|c|}{$\mathbf{2 . 8 0 \%}$} \\
\hline Company's Return & 0.35 & 0.35 & 0.43 & 0.45 & 0.42 \\
\hline Company's Risk & 4.85 & 3.76 & 3.41 & 5.01 & 5.95 \\
\hline Expected Sharp Ratio & \multicolumn{7}{|c|}{$\mathbf{0 . 1 2 6 1}$} \\
\hline
\end{tabular}

Source: Authors Compilation

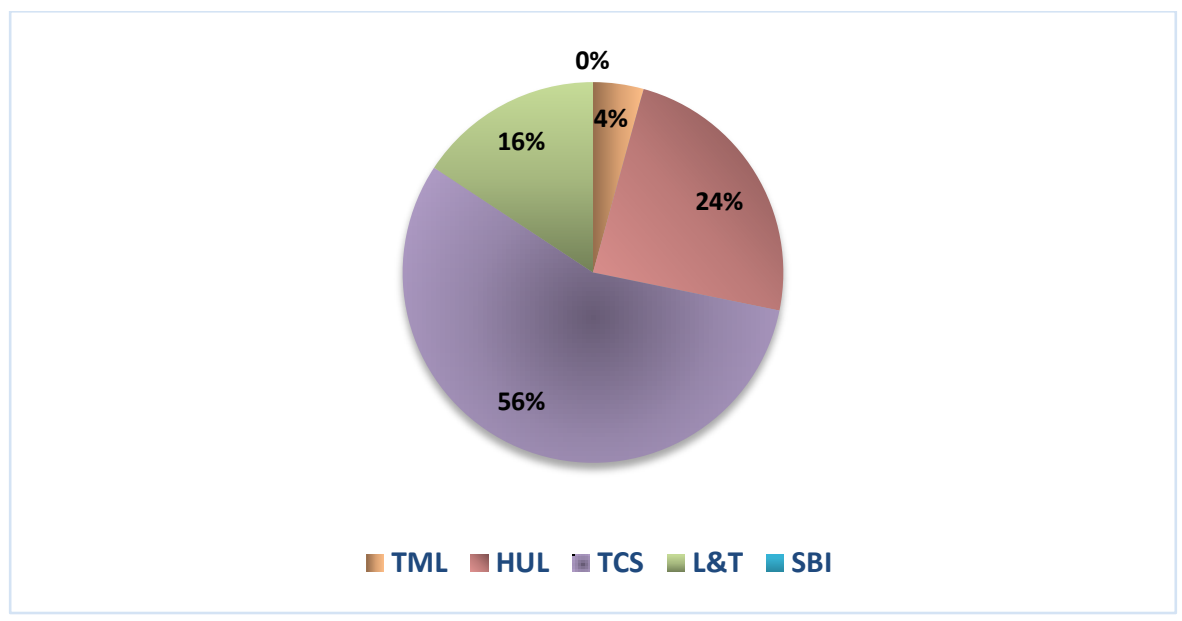

Source: Authors Compilation

From the above Table- 6 and chart, it could be noted that out of 5 stocks considered for arriving at an optimum portfolio through application of sharp optimal portfolio technique, the higher feasible level of sharp ratio was obtained for an portfolio weighting 56 percent of investment on Tata motors limited, 24 percent of the investment in Hindustan Unilever, 16 percent in Larsen \& Toubro and remaining 4 percent in Tata motors limited leaving with no investment in the stock of State bank of India.

Table 7:-Sharp optimum portfolio After Bilateral Trade Tensions

\begin{tabular}{|c|c|c|}
\hline & RIL & SBI \\
\hline Proportion of Portfolio Investment & $\mathbf{0 \%}$ & \multirow{2}{*}{$\mathbf{1 0 0 \%}$} \\
\hline Portfolio Return & \multicolumn{2}{|c|}{$\mathbf{1 1 . 0 5 \%}$} \\
\hline Portfolio Risk & \multicolumn{2}{|c|}{$\mathbf{1 4 0 . 9 6 \%}$} \\
\hline Company's Return & $10 \%$ & $11 \%$ \\
\hline Company's Risk & $142 \%$ & $141 \%$ \\
\hline Expected Sharp Ratio & \multicolumn{2}{|c|}{$\mathbf{0 . 0 8 2 7}$} \\
\hline
\end{tabular}


Source: Authors Compilation

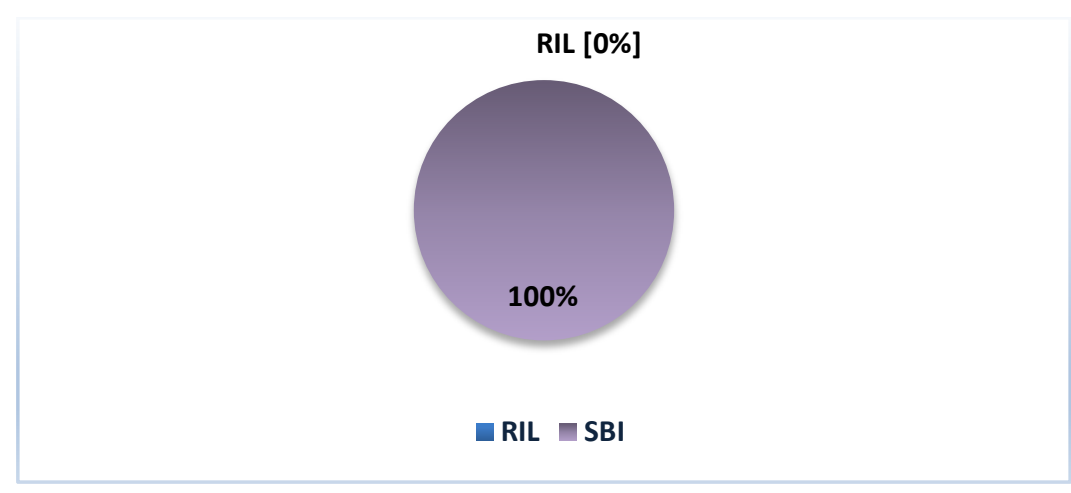

Source: Authors Compilation

From the above Table- 7 and the chart it could be ascertained that the whole amount [100 Percent] of the investment should be invested in a single stock of State Bank of India instead of going for a portfolio investment, since it is evident from the results that after the downgrade of diplomatic ties between the countries the market performance of all the selected companies have declined to a greater extent except the stock value of SBI and Reliance.

The performance of the all the selected companies except state bank of India and Larsen and Toubro have underperformed and has shown the value erosion over the period of last 2.5 years [after the breakdown in bilateral ties]. Therefore after considering the market performance of 8 companies which has been operating in both the countries and has been listed in the stock exchanges in both US and China, the market performance of State Bank of India is performing well and could be included in the portfolio selection.

\section{Conclusion:-}

The accelerating trade war between the two countries had resulted in a serious impact on the country's foreign relationships, the small businesses, farmers, consumers, industries, etc. which intern led to the downturn effecting more of US market economy comparatively severe than that of China's market economy which is evident with this study. At this juncture when both the countries hope of becoming a global power, achieve greater economy, in order to win the global competition and to have a control over the global economy, it couldn't be predicted when this trade war would come to an end. Since the risk is about the misperception in thinking that other country would back down while it keeps escalating. Since a quick deal might not elevate the long term indifference between both the countries ties and also it is hard to make a comprehensive deal which makes both the United States and China feel comfortable with the stringent trade protectionism measures followed by both the countries. With an optimistic view it is pretty sure both the countries have an enticement to come to a deal ever since both the economies are already hurt by this standoff. When it comes to the result of the trade war between US and China, the country which has the most leverage will remain less affected.

With India having the close ties with both United States and China on industries, trade, defense, transportation, and communication aspects it could be noted that the most of the Indian companies which are operating in both US and China when it comes to beta (systematic risk) of the security, the companies have a negative impact on the economic prospects of the company and has led investors less likely to be willing to invest in this climate. But with the systematic approach of selection of an efficient portfolio to invest in a long term slew of stocks as prescribed in this study it would be possible to increase returns by alleviating the risk prospects.

\section{Bibliography:-}

1. De Bondt, W., Thaler, R., 1987. Further evidence on investor overreaction and stock market seasonality. Journal of Finance 42, 557 - 581.

2. Lintner, J., 1965. The valuation of risk assets and the selection of risky investments in stock portfolios and capital budgets. Review of Economics and Statistics 47, 13 - 37.

3. Sharpe, W.F., 1964. Capital asset prices: a theory of market equilibrium under conditions of risk. Journal of Finance 19, 425 - 442. 
4. Ang, J.A. and D.R. Peterson, 1985, "Return, Risk, and Yield: Evidence from Ex Ante Data," Journal of Finance 40, 537-548.

5. Banz, R.W., 1981, "The Relationship between Return and Market Value of Common Stocks," Journal of Financial Economics 9, 3-18.

6. Black, F., M. Jensen, and M. Scholes, 1972, “The Capital Asset Pricing Model: Some Empirical Tests," Studies in the Theory of Capital Markets, M. Jensen, Ed., New York, NY, Praeger.

7. Elton, E.J., 1999, "Expected Return, Realized Return, and Asset Pricing Tests," Journal of Finance 54, 11991220 .

8. http://www.m.moneycontrol.com

9. http://www.yahoofinance.com. 